2. Ших Е. В., Богатырева Л. М., Павлович С. В., Гребенщикова Л. Ю. Влияние витаминно-минеральных комплексов на качество жизни пациентов с артериальной гипертензией. Справочник врача общей практики. 2013. № 2. С. 63-70.

3. Запорожченко М. Б. Характеристика лабораторних показників обстеження жінок репродуктивного віку хворих на поєднану патологію матки: лейоміому та аденоміоз. Вісник Вінницького національного медичного університету. - 2019. - Т. 23. № 1. - С. 120-125

4. Сидоренко А.В. Комплексне лікування поєднаної патології матки: лейоміоми та аденоміозу у жінок репродуктивного віку. дис. доктора філософії:: 222 «Медицина» 2020.

5. Запорожченко М. Б. Сочетание лейомиомы и эндометриоза у женщин репродуктивного возраста. Репродуктивна ендокринологія. 2017. - № 4(36). - С. 24-31.

6. Запорожченко М. Б. Ефективність запропонованої комплексної етапної персоніфікованої терапії у жінок репродуктивного віку із поєднаною патологією матки-лейоміомою та аденоміозом. Здоровье женщุиныl. - 2019. - № 1(137).

7. Ефремов А. И., Матвеевский Н. А., Сафронов И. Д., Пахомова Ю. В. Содержание микроэлементов-антиоксидантов в крови у женщин с миомой и раком тела матки. Медицина и образование в Сибири. 2012. № 1. С. 74-79.

DOI https://doi.org/10.30525/978-9934-26-038-4-17

\title{
ХАРАКТЕР ПАТОЛОГІЧНИХ ЗМІН ЗУБОЩЕЛЕПНОГО АПАРАТУ У ДІТЕЙ 3 ВТОРИННИМИ ЗУБОЩЕЛЕПНИМИ ДЕФОРМАЦІЯМИ НА ТЛІ НЕКОМПЕНСОВАНИХ ДЕФЕКТІВ ЗУБНИХ РЯДІВ
}

\author{
Зражевська А. Ю. \\ магістр медицини, \\ аспірант кафедри ортопедичної стоматології та ортодонтії \\ ПВНЗ «Київський медичний університет» \\ м. Київ, Украӥна
}

Актуальність. Часткова відсутність зубів залишається основною патологією зубощелепного апарату в усі вікові періоди впродовж не одного десятиліття [1]. Відомо, що вторинні зубощелепні деформації, які виникають внаслідок своєчасно некомпенсованих дефектів зубних рядів 
викликають цілий комплекс морфологічних, естетичних і функціональних змін щелепно-лицевої ділянки, що значно ускладнює процес діагностики та ортодонтичного лікування в цілому [2; 3]. На сьогоднішній день, незважаючи на загальне визнання необхідності профілактики, раннього виявлення та лікування порушень оклюзії у дітей, у сучасній літературі не достатньо висвітлена проблема профілактики та усунення рядів і оклюзійних порушень у дітей. Окрім того, проблеми 3 організацією надання стоматологічної допомоги населенню залишається актуальним питанням, що підтверджується значною поширеністю стоматологічних захворювань у всіх вікових групах [4].

Мета: визначити особливості клінічних проявів та характер патологічних змін зубощелепного апарату у дітей з дефектами зубних рядів (ДЗР), ускладнених вторинними зубощелепними деформаціями (ВЗЩД).

\section{Матеріали та методи дослідження.}

Для вирішення поставлених задач нами було обстежено 67 осіб 3 некомпенсованими дефектами зубних рядів віком від 6 до 17 років із застосуванням клінічних методів дослідження, які включали комплексний порівняльний аналіз характеру патологічних змін та оцінку ступеня їх вираженості відповідно періоду прикусу. Усі пацієнти були розділені на дві групи, залежно від їх віку, тобто, періоду формування зубощелепного апарату. Першу групу склали діти зі змінним періодом прикусу, віком від 6 до 11 років 38 осіб, другу - з постійним прикусом, віком від 12 до 17 років - 29 осіб.

\section{Результати досліджень.}

У результаті проведених клінічних досліджень у осіб з некомпенсованими дефектами зубних рядів виявлено високі показники зубощелепних аномалій. Нейтральний прикус спостерігали лише у 10,4\% обстежених. Аномалії прикусу виявлені у 89,6\% дітей серед обох досліджуваних груп. Зокрема, поширеність глибокого прикусу серед дітей обох груп склала $32,8 \%$, а дистального - 28,4\%, перехресний прикус спостерігали у $11,9 \%$ обстежених, а мезіальний та відкритий у 9,0\% та 7,5\%, відповідно. Окрім того, виявлено високий показник аномалій окремих зубів (положення та кількості) - 77,6\% та аномалій форми зубних рядів - 38,8\%, що можна пов'язати з передчасним видаленням тимчасових зубів, особливо в бічних ділянках.

За результатами аналізу анамнестичних даних пацієнтів, які були прийняті на лікування, виявлено, що основною причиною формування ВЗЩД є своєчасно незаміщені дефекти зубних рядів, які виникли на фоні передчасного видалення зубів у 43 осіб $(64,2 \%)$, втрати зубів вна- 
слідок травматичних ушкоджень - 11 (16,4\%), на тлі адентії - 8 (11,9\%) та ретенції зубів - 5 (7,5\%).

Своєчасно некомпенсовані ДЗР практично завжди ведуть до стійких деформацій, які у дітей та підлітків формуються вкрай швидко. Найчастіше зустрічалися ДЗР, ускладнені ВЗЩД у бокових ділянках $92,5 \%$ та на нижній щелепі 53,7\% , внаслідок чого спостерігалось зниження висоти прикусу. За протяжністю відмічали зміни у ділянках дефекту переважно при малих ДЗР - 49,2\% та середніх - 43,3\%, від загальної кількості обстежених дітей в обох групах. Якщо розглядати даний критерій у кожній групі окремо, то у пацієнтів I вікової групи превалювали ускладнення ДЗР середньої протяжності - 60,5\%, а у пацієнтів II групи - малих, що склало 75,9\%.

При огляді пацієнтів 3 вторинними деформаціями зубних рядів 3'ясовано, що патологічні зміни спостерігаються у трьох напрямках. Зокрема, у сагітальному напрямку у $86,5 \%$ серед всіх обстежених, у вертикальному $-71,6 \%$ та у трансверзальному $-15,0 \%$. Комбіновані переміщення були виявлені у $64,2 \%$. У пацієнтів обох групи частіше спостерігали комбіновані переміщення в сагітальному та вертикальному напрямках - 40,3\%, вираженість яких залежала від давності виникнення дефекту, віку пацієнта, та анатомо-фізіологічних параметрів зубощелепного апарату.

Слід відмітити, що у пацієнтів I та II групи було виявлено певні відмінності між видами таких деформацій. Так у пацієнтів I вікової групи комбіновані переміщення у сагітальному та вертикальному напрямках виявлено у 52,6\%. Дентоальвеолярне подовження мали $53,3 \%$ обстежених, нахил зубів у бік дефекту - 47,4\%, корпусне переміщення зубів у бік дефекту - 44,7\%, дентальне подовження у ділянку дефекту $-23,6 \%$, поворот та нахил зубів у ділянку дефекту $-10,5 \%$. У пацієнтів II вікової групи переважали деформації у вигляді нахилу зубів у ділянку дефекту - 62,0\% та дентальне подовження - 34,5\%, а комбіновані переміщення спостерігали у $24,1 \%$ обстежених.

Результати наших досліджень збігаються з більшістю авторів. За відсутності тимчасових молярів на одній щелепі, при збереженій цілісності зубного ряду на протилежній, відбуваються зміни з боку зубощелепного апарату у вертикальній площині. Таким чином виникає дентоальвеолярне подовження, що надалі перешкоджає повному прорізуванню премолярів при їх фізіологічній зміні, оскільки до того часу вертикальні деформації можуть досягати рівня протилежного альвеолярного відростка [3-6]. 
Все наведене вище свідчіть про необхідність подальшої розробки та удосконалення алгоритму проведення диференційної діагностики, методів профілактики та лікування ВЗЩД у дітей.

Висновки. Роль тимчасових зубів важлива в процесі становлення висоти прикусу, в правильному формуванні зубних рядів і щелеп, своєчасному прорізуванні і правильному розміщенні постійних зубів в зубній дузі та нормальному розвитку зубощелепного апарату в цілому.

Своєчасно некомпенсовані дефекти зубних рядів слугують основною причиною розвитку ВЗЩД, зниження висоти прикусу та функціональних порушень, які в свою чергу, ускладнюють ортопедичне і ортодонтичне лікування та потребують спеціальної підготовки порожнини рота. Тому особливого значення набуває проведення профілактичної роботи серед дитячого населення 3 метою раннього виявлення порушень з боку зубощелепного апарату для своєчасного їх ортодонтичного лікування та зубного протезування, що дозволить попередити виникнення стійких деформацій щелепно-лицевої ділянки.

\section{Література:}

1. Крупник А.-С. А. Обгрунтування можливості використання імплантів для заміщення дефектів зубних рядів у підлітків. Автореф. канд. дис. Львів, 2018.

2. Король М. Д., Нідзельський М. Я., Король Д. М., Дорубець А. Д. Вторинні деформації зубних рядів. Полтава, 2016.

3. Лабій Ю. А., Гавалешко В. П., Рожко В. І., Котельбан І. С. Протезування дефектів зубних рядів у дітей: проблеми, можливості та шляхи вдосконалення (огляд літератури). Вісник проблем біології i медииини. 2019. № 4. С. 28-33.

4. Каськова Л. Ф., Марченко К. В., Бережна О. Е. Поширеність зубощелепних аномалій у дітей $з$ урахуванням шкідливих звичок та відношення до ортодонтичного лікування. Вісник украӥнської медичної стоматологічної академії. 2015. № 1. С. 17-20.

5. Лабунець О. В. Комплексна характеристика стану стоматологічної ортопедичної захворюваності та допомоги у осіб молодого віку. Інновації в стоматологіï. 2014. № 4. С. 131-137. 